\title{
An Evidence-Informed Picture of Course-Related Copying
}

\section{Rumi Graham}

\begin{abstract}
Recent changes in Canadian copyright law have prompted Canada's educational institutions to reexamine their need for a blanket copying license. Users' rights under the amended Copyright Act now include fair dealing for purposes of education, and the Supreme Court has established that copying short excerpts for classroom use can qualify as fair dealing. This study looks at one university's examination of copied course materials made available via library reserve, coursepacks and its learning management system, and likely sources for copyright permissions, when needed. Results suggest that fair dealing is the most important and the institution's blanket license is the least important basis for permissions clearance over a semester's worth of copying.
\end{abstract}

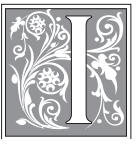

n 2012, a surge of seismic shifts in the Canadian copyright landscape swept postsecondary institutions, along with the educational community at large, into new copyright territory. In the unsettled two-year period leading up to those changes, publicly funded universities and colleges outside Quebec began to grapple with the thorny issue of whether to retain the blanket collective copying license most had held since the 1990s or to change course by managing copyright permissions outside a blanket license. ${ }^{1}$ Determining the appropriate path forward was a perplexing matter on several counts that, for some institutions, included uncertainty regarding the kinds and volume of copying performed on campus. In general, without a complete and accurate picture of institutional copying, it is not easy to determine the copyright permissions actually needed by an institution, much less whether blanket licensing is a cost-effective way to cover a significant portion of those permissions.

The copyright permissions of chief concern to postsecondary institutions do not pertain to materials copied by a student or faculty member for his or her own personal research or study. This is usually the case due to established academic practice, which considers such copying to be covered by the statutory infringement exception called fair use in the United States and known as fair dealing in Canada and other countries that derive their national laws primarily from English common law. ${ }^{2}$ Instead, the focus of permissions management is most often on instructor-selected materials copied for use by enrolled students. Here, too, it is possible for properly conducted fairness analyses to conclude that particular instances of making copies available to students for classroom use, on the whole, qualify as fair dealing or fair use, ${ }^{3}$ but there is a widespread lack

Rumi Graham is University Copyright Advisor \& Graduate Studies Librarian at the University of Lethbridge; e-mail: grahry@uleth.ca. ( 2016 Rumi Graham, Attribution-NonCommercial (http://creativecommons.org/licenses/by-nc/3.0/) CC BY-NC. 
of consensus regarding the kinds of teaching-related copying that may reasonably be covered by exceptions to copyright infringement. ${ }^{4}$

Against the backdrop of a rapidly evolving copyright landscape and divergent views on the kinds of educational copying requiring permission, this study was undertaken at a Canadian university to explore whether a full picture of course-related copying could be assembled to determine the permission sources most needed by the institution. Evaluations of the value of blanket licensing often touch on issues of coverage overlap or completeness, costs, onerous reporting or survey participation requirements and operational workload issues, but weighing the permissions afforded by a blanket license against an institution's actual permissions needs is infrequently addressed. ${ }^{5}$ Nonetheless, from the perspective of evidence-based practice, which aims to routinely gather, evaluate, and use relevant information for all workplace problem solving, deciding whether or not an institution needs a blanket copying license is ideally informed by a variety of considerations that include substantiated facts about the copyright status and permission sources of materials copied by instructors for teaching purposes. ${ }^{6}$

The practical obstacles to gathering comprehensive data on an institution's educational copying are by no means insignificant, since much of it likely occurs as electronic distribution of materials that may not be tracked in a way that supports permission analyses. Furthermore, as selecting course content and choosing the means of distribution are typically matters protected by instructors' academic freedom, collecting information about copied materials for permission analysis purposes in some cases may require instructors' consent or active participation. As well, the logistics of gathering data on all course-related copying could be overwhelmingly complex, especially for large institutions. These challenges notwithstanding, the research problem examined in this study is incomplete understanding of the copyright status of course materials and their permission sources, which hampers the ability of institutions to make informed decisions on copyright policy, practice, and resource allocation that are grounded in reliable data capturing the overall scope of educational copying.

This study assembles a holistic, evidence-based picture of a Canadian university's course-related copying. It aims to increase understanding of the materials copied and shed light on the extent to which permissions are needed beyond users' rights provided under the Canadian Copyright Act, institutional electronic resource licenses, open access licenses, and cost-free copyright owner permission. As copyright law is territorial, the copyright and permission analyses discussed here pertain to Canadian educational institutions, but the underlying research problem and research approach may be broadly relevant to postsecondary institutions in other legal jurisdictions. The following section situates this study by outlining the context in which approaches to permissions clearance for Canadian educational copying have evolved over the past twenty-five years, the roles played by key entities and events leading up to the radically revised understanding of the scope of fair dealing for teaching purposes that unfolded in 2012 and the study's institutional setting.

\section{Background}

Dissonant views on the applicability of fair dealing to research and education in Canada were evident from the initial blanket photocopying licenses for schools, colleges, and universities negotiated after the first literary works collectives were established pursuant to Copyright Act amendments passed in 1988. ${ }^{7}$ With little case law to guide interpretations of fair dealing in Canadian educational contexts, ${ }^{8}$ postsecondary institutions acquired blanket licenses primarily as an expedient way to cover permissions possibly needed for instructor-selected course readings produced as printed collections called coursepacks. The collective license held by universities was based on a model 
license agreement negotiated by the Association of Universities and Colleges of Canada (AUCC) and CANCOPY, now known as Access Copyright, that was finalized in $1994 .{ }^{9}$ A similar agreement was negotiated shortly thereafter by the Association of Canadian Community Colleges (ACCC) and CANCOPY for colleges and technical institutes. ${ }^{10}$ The model license agreements were subsequently renewed periodically.

Postsecondary collective licenses in effect up to 2010 covered two main types of copying. Copying for "private use" involved a flat tariff based on the number of fulltime equivalent (FTE) students. Coursepack copying was subject to a per-page tariff and reporting on how much of a work was copied and number of copies made. ${ }^{11}$ Two elements of the AUCC license agreements highlight the distance between the parties' stances on fair dealing. First, disagreement on the scope of fair dealing is stated explicitly in every agreement's preamble. ${ }^{12}$ Second, each agreement contains a clause expressing agreement to disagree on whether making a single copy of a covered work without permission infringes the owner's copyright. ${ }^{13}$ By giving staff and students "the right to make copies of published works for the purpose of education or recreation associated with the institution" and indemnifying licensees for copying works outside the collective's repertoire, ${ }^{14}$ the license agreements sidestepped the issue of whether, and under what circumstances, copying might represent a justified exercise of fair dealing.

Thus, an uneasy albeit relatively stable blanket collective licensing arrangement existed across Canadian educational institutions for about fifteen years. ${ }^{15}$ But in the fall of 2009 , heightened unrest was triggered by preparations for a new round of negotiations between AUCC and Access Copyright, as the then-current agreement was set to expire in 2010. This time, discussions were to include digital as well as reprographic copying. When a new agreement failed to materialize, in March 2010 the collective exercised the second of its two statutory options for setting licensing rates, terms, and conditions by filing a proposed tariff with the Copyright Board. ${ }^{16}$ This was not the collective's first educational tariff.

In 2004, the collective filed a proposed 2005-2009 tariff for public schools (K-12), to which the Council of Ministers of Education (CMEC) representing all provinces except Quebec filed objections that included issues related to fair dealing. Unhappy with the Copyright Board's tariff decision in 2009, CMEC sought judicial review. ${ }^{17}$ After a 2010 Federal Court of Appeal ruling largely upheld the Board's decision, CMEC sought and was granted leave to appeal to the Supreme Court of Canada. ${ }^{18}$

Predictably, the postsecondary sector viewed many aspects of the proposed 2011-2013 postsecondary tariff to be problematic, leading AUCC, ACCC, and a number of individuals, colleges, and universities to file notices of objection with the Copyright Board. ${ }^{19}$ Thus began another protracted tariff certification process for copying by Canadian educational institutions that, as of this writing, has not yet concluded..$^{20}$ Among the most controversial aspects of the proposed postsecondary tariff are its all-in-one royalty rate per FTE student for print and digital copying representing a thirteen-fold increase over the rate in the last negotiated model license agreement covering only print reproduction; a definition of "copy" that includes posting a link to, projecting, and displaying a digital copy; and a requirement for institutions to give the collective "full access to the Secure Network and all Course Collections" to enable surveying of copied works. ${ }^{21}$

With no prospect of having a certified postsecondary tariff in place by January 2011, in late December 2010 Access Copyright obtained an approved interim tariff for 2011-2013 containing terms and conditions closely mirroring those of the blanket licenses that expired in 2010.22 A number of institutions declined to avail themselves of the interim tariff, however, thereby beginning a movement away from the blanket licensing regime. ${ }^{23}$ Among the main reasons for this change was the fact that most universities already held numerous license agreements, often consortially negotiated directly with 
publishers, covering broad educational and scholarly uses of electronic full-text content that not infrequently overlapped the repertoire Access Copyright purported to license. Hence, universities' often-expensive publisher licenses meant that blanket licensing was not a cost-effective approach to managing permissions unless coverage duplication was accounted for in the collective license terms.

While Copyright Board tariff proceedings were ongoing, tensions mounted as copyright came under national scrutiny with the September 2011 introduction of Bill C-11, another attempt to complete a Copyright Act reform process initiated ten years earlier that seemed likely to succeed, in part due to the majority government. ${ }^{24}$ The copyright spotlight widened in December 2011 when the Supreme Court heard a set of five copyright cases informally known as the "pentalogy," 25 which included the K-12 tariff appeal. A month later, Access Copyright and two universities disclosed the conclusion of new license agreements containing terms and conditions comparable to those of the proposed postsecondary tariff, aside from a lower royalty rate. ${ }^{26}$ Some viewed this turn of events with dismay as the outcomes of highly relevant legislative and judicial proceedings were not yet known. ${ }^{27}$ And then in April 2012, Access Copyright and AUCC announced agreement on a new model license similar to the agreements signed by the two breakaway institutions, thereby reflecting most of the disquieting aspects of the proposed tariff. ${ }^{28}$ A similar agreement for colleges and institutes was unveiled in May 2012. ${ }^{29}$

April to June 2012 was a turbulent period for Canadian postsecondary institutions as they weighed options for managing copyright amid uncertainties about outcomes of the tariff proceedings, Bill C-11, and the pentalogy cases and about the advisability of signing a new blanket license at deeply discounted rates available only to the end of June. As things turned out, Bill C-11 received royal assent on June 29, 2012, , $^{30}$ thereby adding education, parody, and satire as fair dealing purposes under the Copyright Act; $^{31}$ two weeks later, the Supreme Court released its pentalogy decisions. The K-12 tariff decision-Alberta (Education) v. Access Copyright-addressed whether public school teachers' copying of short excerpts for classroom use can qualify as fair dealing. To reach its decision, the Court applied the broad and liberal interpretation of fair dealing mandated in its 2004 decision in CCH v Law Society of Upper Canada, which yielded the conclusion that fair dealing, properly assessed, can apply to educational copying. ${ }^{32}$ Equally important is the reconfirmation in another pentalogy decision-SOCAN

Bell-that fair dealing, like all infringement exceptions, is a users' right, a view first espoused by the Court in $\mathrm{CCH}^{33}$

The desirability of gathering comprehensive copyright and permissions data for educational copying became apparent to the researcher in light of copyright law reform processes in Canada and elsewhere ${ }^{34}$ that seem likely to be ongoing, and the need for institutional copyright policies and practices not only to evolve with changes in the law, but also to bolster teaching, learning, and research mandates. At the University of Lethbridge where the researcher has served as copyright advisor since 2011, permission analyses are conducted by the copyright advisor office (CAO) for coursepack and library reserve readings. Since faculty are responsible for clearing copyright for all other course-related copying, the CAO is not involved, except on request, in assessing permissions for readings distributed via other means, the most common of which is the university's learning management system (LMS). The copyright status and permission source for course materials distributed via the LMS is a data gap the researcher became interested in trying to fill.

Founded on liberal education principles in 1967, the University of Lethbridge is a public university operating under the Alberta Post-Secondary Learning Act as a comprehensive academic and research institution. About 500 full- and part-time academic 
staff deliver undergraduate and graduate degree programs offered on campuses in Lethbridge, Calgary, and Edmonton, Alberta to about 8,200 full- and part-time students. ${ }^{35}$ From 1995 to 2010, the university held a series of blanket photocopying licenses based on the model agreements negotiated by AUCC and Access Copyright. In 2011, the institution was covered by the interim postsecondary tariff to the end of the summer but began to operate outside the tariff from the fall semester at the same time the CAO office was established.

The June 2012 signing of a new collective license covering January 2011 to December 2015 provided an opportunity to collect data required for a permissions analysis of LMS course materials without concerns that could otherwise arise if an investigation of this type were to occur outside a blanket license.

This study tries to fill the data gap on copying in the university's LMS and then combines the LMS data with existing data on coursepack and library reserve copying to compile a holistic picture of copied materials and their likely sources of needed permissions. The following research questions guide this study:

1. How do the kinds of copied course materials distributed via the LMS compare with those made available to students as coursepacks and reserve materials?

2. How do the probable sources of permission for LMS course readings compare with the permission sources for coursepack and reserve readings?

3. Given the kinds of materials copied as course materials and their probable permission sources, what are the permissions management implications for the university?

\section{Literature Review}

Many challenges of developing and applying balanced copyright policies and practices in print-dominated academic library settings are intensified when new copying and dissemination technologies emerge. ${ }^{36}$ Copyright is thus regularly featured in the literature on library-mediated electronic distribution of course readings that has been accumulating since the early 1990s with a predominant focus on electronic reserves (e-reserves) ${ }^{37}$ most of which applies to U.S. law. ${ }^{38}$ Less prevalent discussions and research on copyright in contexts inclusive of reserves, coursepacks, and the institutional LMS may be due in part to a tendency for administrative responsibility for coursepack production and the LMS to lie outside the library and to potential differences in how copyright law applies in e-reserve, LMS, and print reproduction environments. ${ }^{39}$ In any case, it appears that few studies have probed copyright and permission issues related to course materials across common distribution modes, which include print and electronic reserve, print and electronic coursepack, and institutional LMS. Concerns have been raised, however, about copyright implications of replacing coursepacks and library reserves with LMS postings. ${ }^{9}$

Studies addressing copyright issues in LMS environments to date are relatively sparse. Some investigations discuss elements of copyright compliance education and guidance that should be provided for faculty who use their institutional LMS. ${ }^{40}$ Several studies describe the establishment of complementary interrelations between the academic library e-reserve system and the institutional LMS to provide online access to course readings in an integrated, copyright-compliant manner, with permissions clearance often mediated by library staff. ${ }^{41}$ A survey of copyright compliance practices in LMS and e-reserve systems at U.S. public liberal arts colleges reports that permissions clearance is often the responsibility of faculty members. ${ }^{42} \mathrm{~A}$ broader survey of U.S. and Canadian academic libraries on their e-reserve services reveals a permissions clearance service continuum that, at one end, eliminates library involvement: "full service" provides library coverage of all aspects of e-reserves service including per- 
mission fees; "self-service" is managed entirely by faculty and nonlibrary staff in the LMS with discontinued library e-reserve service; and "hybrid service" covers service approaches that fall between full service and self-service. ${ }^{43}$

\section{Methods}

This study uses an evidence-based practice approach to address the research problem of incomplete understanding of the copyright status of educational copying and applicable permission sources. Evidence-based library practice is essentially guided by a commitment to habitually use basic principles of sound research to solve workplace problems by formulating a problem, searching for needed evidence, evaluating the evidence, applying results, and evaluating outcomes. ${ }^{44}$ This study's research problem is formulated as the above three research questions on materials copied for University of Lethbridge courses, their copyright status and permission source, and implications for permissions management. The search for evidence involved filling a data gap on the copyright status and permission source for LMS-distributed copied materials. Evaluating the evidence was accomplished by conducting copyright and permissions analyses using the tools and concepts employed in everyday CAO permissions clearance work. Applying results was carried out by responding to the research questions. Evaluating outcomes involved assessing the extent to which the questions are answered and identifying limitations of the study and possible further research.

It is useful to think of the various data compiled and analyzed in this study as forming a bounded "case" - one semester's worth of educational copying. The case examined in this study is spring 2012 course-related copying at the University of Lethbridge. Because it was preferable, for logistical reasons, to collect the missing LMS data from courses belonging to a noncurrent semester, spring 2012 was selected as it was the most recently completed semester when planning for the study commenced.

Since most of the university's courses are offered in the fall and spring semesters and they both comprise similar mixes of course levels and subject matter, either semester is likely to be representative of courses offered over a school year. Spring 2012 therefore serves as a representative case. The materials of principal interest in this study are print and digital course materials made available via the university's LMS, library reserve, and coursepacks. Copyright and permissions data for reserve readings and coursepacks were gathered in the spring 2012 semester as a part of normal CAO activities. Data collection and coding therefore focused on spring 2012 LMS course materials.

\section{Data Collection and Coding}

To enable full consideration of the study's research questions, the researcher sought permission to access all LMS courses used in spring 2012 courses via an ethics committee-approved research protocol. Aided by a list generated by the registrar's office, all University of Lethbridge instructors who taught one or more spring 2012 courses were contacted by e-mail in the fall 2012 semester to describe the present investigation and request responses to two questions: a) whether the instructor had used the LMS in spring 2012 for any purpose for each course taught, and b) when the LMS had been used, whether consent was granted to the researcher to access the instructor's spring 2012 LMS course or courses in "auditor" mode, meaning that no confidential information about individual students or grades would be visible or accessible.

The researcher manually recorded descriptive information about each item viewed in an LMS course and its copyright- and permissions-related data using a spreadsheet adapted from a template used in CAO permissions analyses for coursepack and reserve readings. A separate spreadsheet data file was created for each viewed LMS course, and the adopted conventions for naming files and recording data were designed to protect 
the anonymity of courses and instructors. Data was collected in a manner supporting only aggregated information about course level (examples: first-year undergraduate studies, masters), instruction type (such as course or lab) and seven broad disciplinary areas (education, fine arts, health sciences, humanities, management, sciences, and social sciences).

Using Microsoft Access, a data coding form was created to facilitate coding of the spreadsheet data files. The coding form contained three subforms that tracked details pertaining to a) a viewed LMS course and, within the course, b) each instructor-authored item and c) each item authored by one or more individuals other than the instructor. A research assistant populated a separate data coding form for every spreadsheet data file. The researcher used the resulting Access database to generate descriptive statistics on the courses viewed and the copyright status and probable permission source for LMS materials. Data collection and coding occurred during fall 2012 and spring 2013.

In the data collection phase, the question of probable permission source was only addressed for items appearing to be authored by individuals other than the course instructor, since copyright permission was not at issue for works authored by course instructors. Determination of the probable permission source of items was necessarily an interpretive exercise based on the attribution information visible to the researcher. Neither data collection nor data analysis involved determining whether permission, if it appeared to be needed, was actually in place during the spring 2012 semester.

\section{Data Analysis}

For analysis purposes, all data on spring 2012 course materials distributed via the LMS, library reserve, and coursepacks needed to be organized in a manner permitting the research questions to be addressed. Initially, the second research question posed a challenge because it calls for a comparison of permission sources for LMS, coursepack, and reserve readings, which in turn depends on a consistently applied view of the kinds of copying requiring permission. As permission analyses for coursepack and reserve readings were completed prior to the momentous mid-2012 changes in Canadian copyright law, they reflected a much narrower understanding of fair dealing than the "fair dealing consensus" ${ }^{\prime 5}$ reflected in the newly revised fair dealing guidelines issued by several educational organizations. ${ }^{46}$ Permissions cleared before and during the spring 2012 semester therefore produced results that were qualitatively different from permissions cleared after the summer 2012.

To enable meaningful comparative and combinative analyses of permission sources for readings considered in this study, all spring 2012 coursepack and reserve readings were reassessed using the understanding of fair dealing applied by the CAO in copyright permissions assessments since the fall 2012 semester, which is outlined in the University of Lethbridge's revised fair dealing guidelines ${ }^{47}$ The major change between spring and fall 2012 analyses of fair dealing is the post-Alberta (Education) understanding that course-related copying by educational institutions can, within certain limits, qualify as fair dealing under the Copyright Act. In practice, this often means permission for a course reading sought in spring 2012 or earlier is now no longer sought because the copying - perhaps a single article from a journal issue, or a single chapter from a multichapter book - falls within copying described in the university's revised guidelines as likely to be fair.

Analysis of the copyright status of a work (whether it is protected by copyright in Canada) was guided by the following concepts pertaining to what copyright does and does not protect:

- original work: As the Copyright Act states that "copyright shall subsist in Canada... in every original... work" meeting specified conditions, ${ }^{48}$ works lacking 
originality are not protected. Given the Supreme Court's ruling in $\mathrm{CCH}$ that originality in a work involves the exercise of skill and judgment going beyond a trivial mechanical exercise but without a need for the result to be novel or unique ${ }^{49}$ materials chiefly consisting of facts or raw data (such as spreadsheets and other data files containing numeric values for statistical computations) are regarded as unprotected by copyright because they lack originality.

- public domain: Because the term of copyright in Canada is limited under the Act to the life of the author plus fifty years, ${ }^{50}$ works authored by individuals who died more than fifty years ago are no longer protected by copyright. A work whose copyright term has expired is part of the public domain, thereby not requiring permission or fee payment.

- substantial part: The meaning of "copyright" under the Act is the sole right to produce or reproduce, perform in public, or publish a "work or any substantial part thereof." ${ }^{51}$ Copying an insubstantial part therefore does not infringe copyright. David Vaver notes a "part" does not mean a "particle": "A copyright owner cannot... control every particle of her work, any little piece the taking of which cannot affect the value of her work as a whole." 52 Furthermore, in Warman v. Fournier, the Federal Court of Canada said "whether a substantial part of a work has been reproduced is a question of fact and involves a qualitative rather than quantitative analysis." 53 Brief quotations common to academic writing that do not affect the market value of the work as a whole are thus regarded as insubstantial parts not protected by copyright.

- Web links: In Crookes v. Newton, a case addressing whether hyperlinking constitutes publication, the Supreme Court of Canada stated that "making reference to the existence and/or location of content by hyperlink or otherwise, without more, is not publication of that content," ${ }^{54}$ which suggests in most educational contexts, providing a link does not constitute copying the material pointed to by the link. Web links to course content are therefore regarded as not protected by copyright.

In general, copying or distributing copies of copyright-protected material requires owner permission to avoid infringing owners' rights. Analyses of probable permission sources for copied works drew on the following possible sources, cost-free sources, and sources permitting the broadest uses being preferred when multiple sources appeared to be available:

- author: For some course materials, the copyright owner is an individual known to the instructor (for instance, an exemplar essay authored by a previously enrolled student or lesson slide files created by external guest lecturers). In such cases, the author is the permission source, and permission fees are unlikely.

- collective license: Although the university operated as an opt-out institution during the spring 2012 semester, its blanket license signed in June 2012 provides retrospective permissions coverage back to January 2011 for works in the Access Copyright repertoire.

- fair dealing: The Copyright Act provides users' rights (infringement exceptions) permitting copying in certain limited situations that do not require owner permission or fee payment. One example is fair dealing for the purpose of research, private study, education, parody, satire, criticism, review, or new reporting, with the proviso for the latter three purposes that the user provides source attribution. ${ }^{55}$ Assessment of fair dealing is guided by the Supreme Court's decision in Alberta (Education) and the Court's two-step fair dealing test delineated in $\mathrm{CCH}$. The first step asks if a dealing with a work is for a statutory fair dealing purpose, which can be answered affirmatively for all course-related copying, as instructors' purposes undoubtedly include education, research, or private 
study. The second step evaluates the fairness of the dealing in terms of six suggested factors - the purpose, character, amount and effect of a dealing, the nature of the work, and alternatives to the dealing - although factors relevant to a particular instance of copying are neither restricted to nor are required to include the six identified by the Court. ${ }^{56}$

- library license: The terms of many library licenses for online full-text databases and collections permit use of licensed content as course readings (for example: downloading an e-book chapter to an LMS course or copying a journal article in a coursepack). ${ }^{57}$

- open access: Some copyright owners publish their works under open access or Creative Commons licenses ${ }^{58}$ that permit educational uses without the need to obtain owner permission.

- $\quad$ publisher agreement: Some textbook publishers permit instructors to access free teaching materials keyed to a particular textbook when instructors adopt the textbook for their course. Use of such materials is usually governed by terms and conditions of the publisher's end user agreement. Publishers may also permit fee-free copying of short excerpts for educational purposes if the excerpts are taken from the textbook adopted for the course.

- rights holder: Applicable only in viewed LMS courses, rights holder designates a permission source presumed to possibly involve payable fees. It pertains to materials that lacked attribution. Without attribution information, it was impossible to investigate whether a transactional (pay-per-use) license was available.

- transactional license: This permission source designates a license that is available from a publisher or the Copyright Clearance Center ${ }^{59}$ permitting one-time educational use (examples: a business case, or a book chapter posted in the LMS or reproduced in a coursepack).

- available via Internet: A new users' right added to the Copyright Act in 2012 permits educational institutions to use a "Work available through Internet" for educational purposes if the user provides source attribution, access to the work is not restricted by technological means, and there is no clearly visible notice prohibiting the desired use. ${ }^{60}$

\section{Results}

\section{LMS Courses and Materials}

Of 530 instructors who taught one or more spring 2012 courses and received a consent request for this study, 83 percent responded. Just under one half of all instructors said they used the LMS, and just over one third said they did not use the LMS at all. Of respondents who used the LMS, 89 percent granted LMS course access to the researcher. Of the 11 percent of respondents who used the LMS but did not provide consent, more than one-third did not deny access explicitly but instead indicated they had not used copyrighted materials other than those authored by themselves.

A comparison of the disciplinary distribution of courses involving LMS use to the disciplinary distribution of the university's total credit hours taught in spring 2012 reveals a roughly proportionate correspondence, suggesting that the disciplinary mix of LMS courses examined in this study is similar to that reflected across all spring 2012 course offerings. ${ }^{61}$ The researcher was granted permission to access and view the course content of 484 LMS courses. The LMS findings described below pertain to the 348 LMS courses accessed with instructor permission containing at least one course-related work viewed by the researcher. ${ }^{62}$

The assessed LMS courses fall into two main categories: courses containing only instructor-authored content and courses containing a mix of materials authored by 
instructors as well as materials authored by individuals other than the university's instructors. The authorship of course materials in 81 percent of the assessed courses was mixed. Almost all of the rest of the courses contained only materials created by one or more instructors. In a single outlier course, all course materials appeared to be authored solely by individuals other than the university's instructors.

The most common types of course content authored by course instructors were lesson slides (such as PowerPoint files), assignments and exercises and lesson notes, collectively accounting for two-thirds of instructor-authored content (see figure 1). About 95 percent of the LMS courses with viewable content contained a course syllabus or outline.

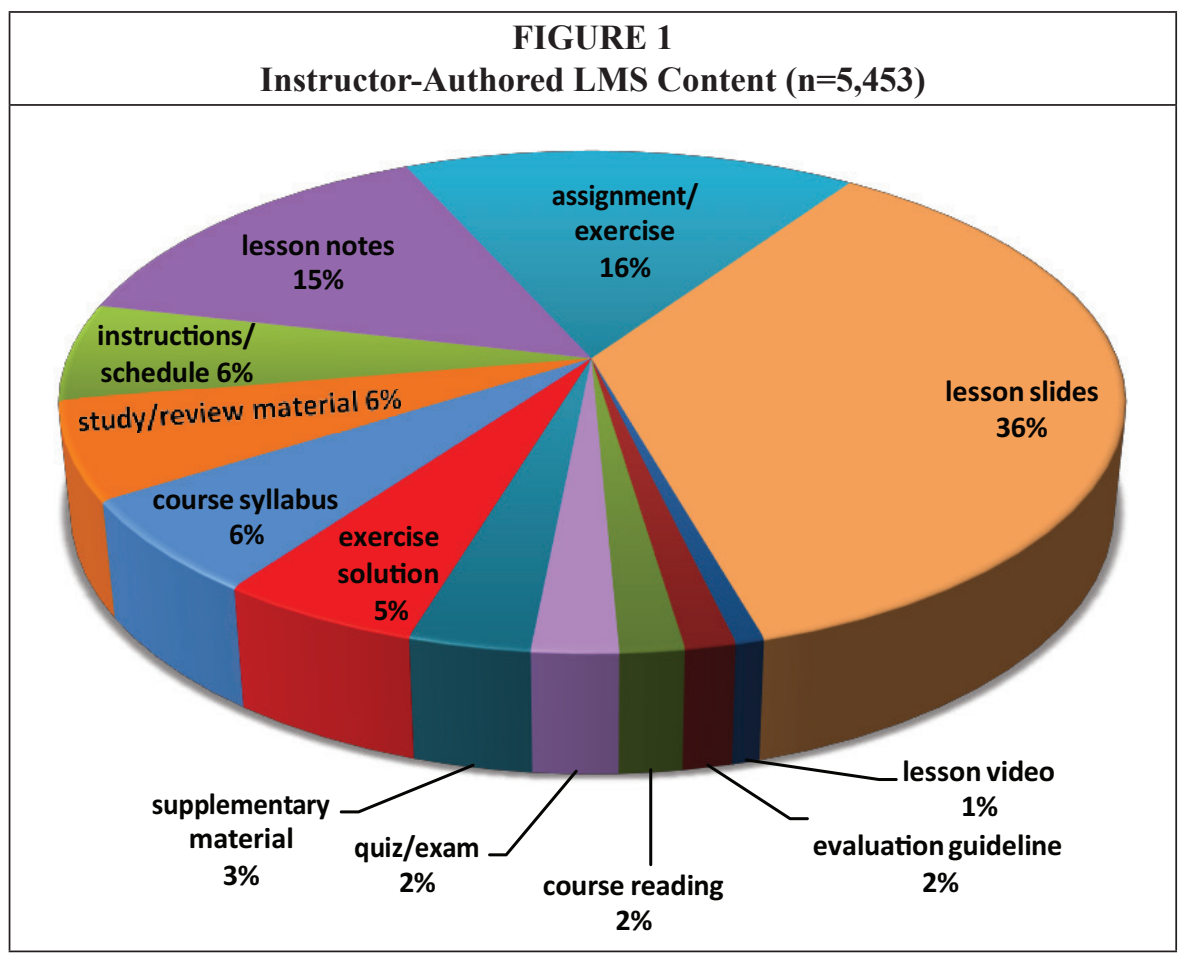

The types of materials used in LMS courses that were not authored by the instructor were divisible into two groupings: readings and resources. In the main, readings were text-based or notated works that appeared to relate to course-specific content described in course syllabi (see figure 2). The most frequently encountered type of reading was course textbook publisher material-supplementary publisher-created content keyed to a particular textbook such as lesson slide files, lecture notes, and chapter problems and solutions, ${ }^{63}$ followed closely by journal article, which together account for more than half of the non-instructor-authored readings viewed in the LMS.

Resources, the second group of non-instructor-authored materials, are almost entirely nontextual in nature (see figure 3). The one exception is the category called research/ writing guide, which designates content similar to the readings group's instructional material category but were presented as general study aids rather than as course-specific content. Just more than half of the resources were visual materials (graphic, photograph, chart/graph, cartoon). Web resources were materials presented as publicly accessible 


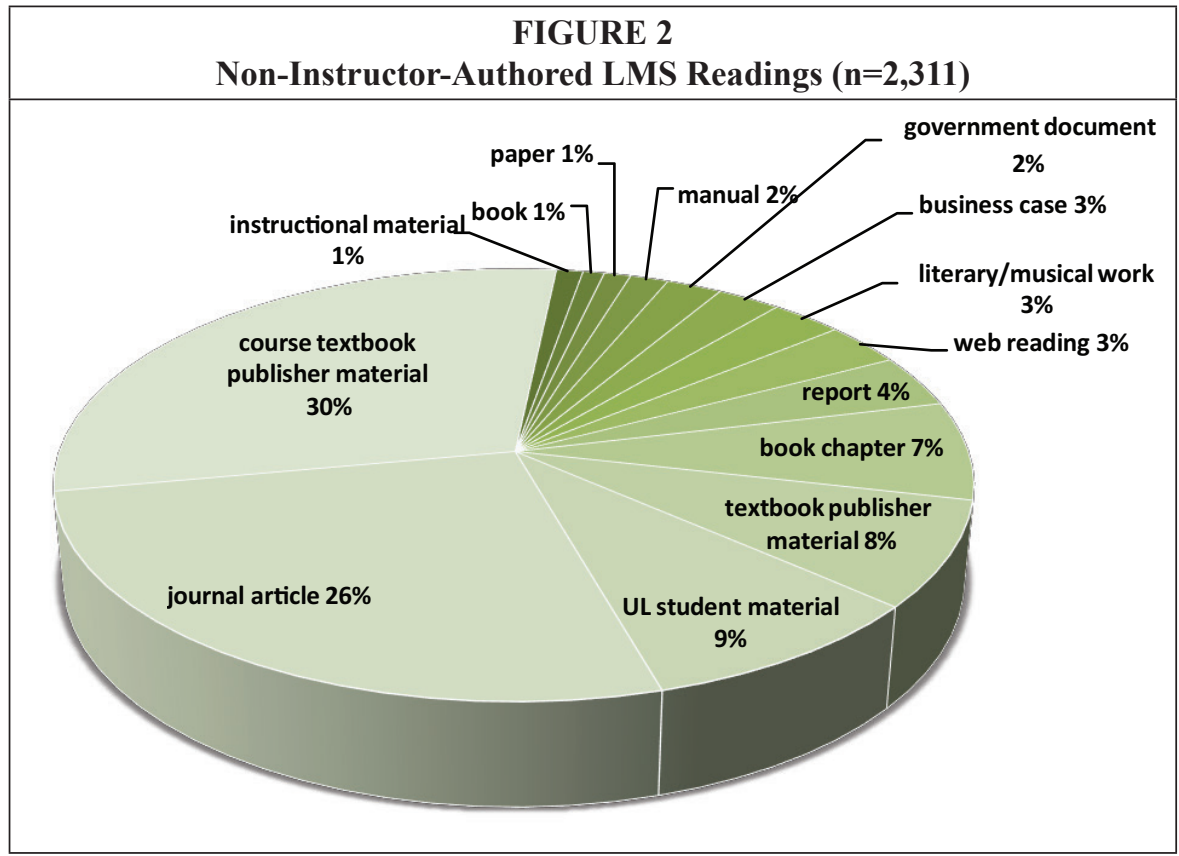

links (such as links to YouTube videos or audio recordings). Most of the images and maps were embedded in instructor-authored lesson slides.

Permission analyses for LMS materials not authored by the instructor are presented in figure 4. Two clusters of materials generally not protectable by copyright were identified: web links (24\%) and data files (4.5\%). A very small group comprising public domain materials did not require permissions. Of the materials determined to be protected

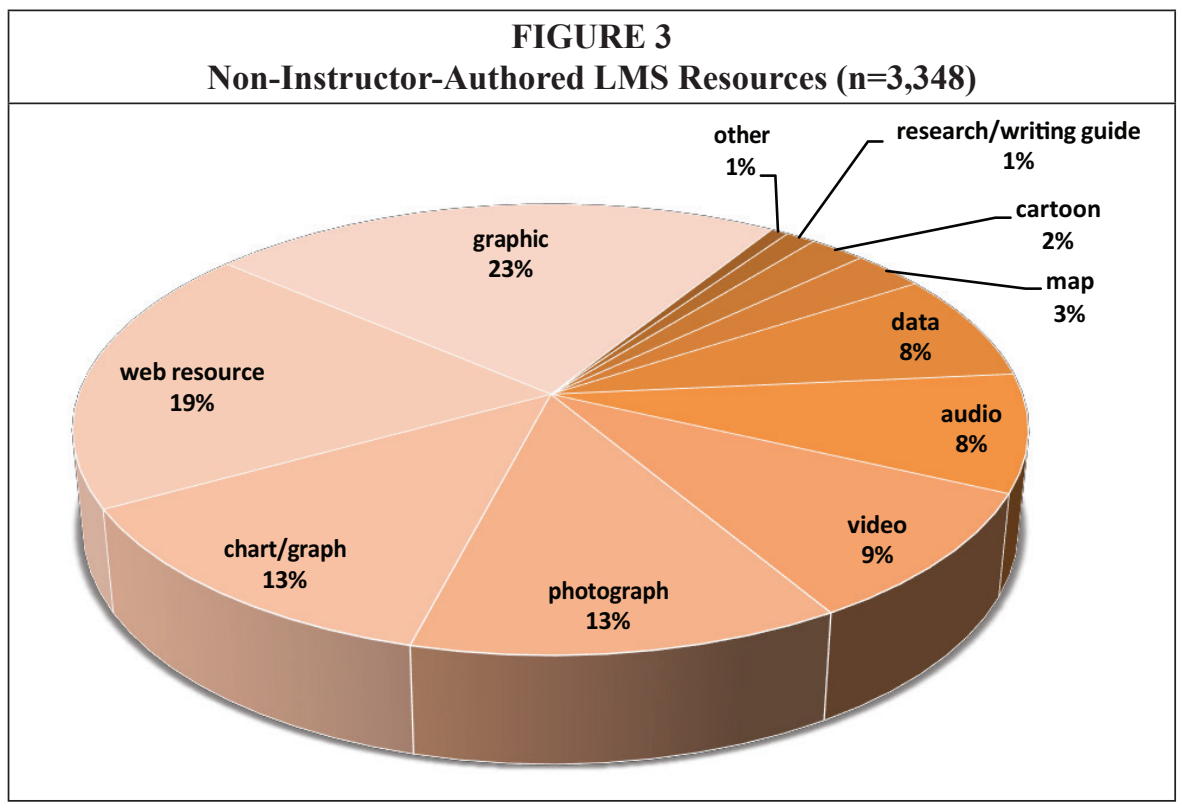


by copyright, publisher agreement was by far the most frequently encountered probable permission source. Library license, fair dealing, and author, in roughly equal proportions, together account for about the same percentage of probable permission sources as publisher agreement. The remaining permission sources - rights holder, open access/available via Internet, and collective/transactional license-infrequently appeared to be applicable.

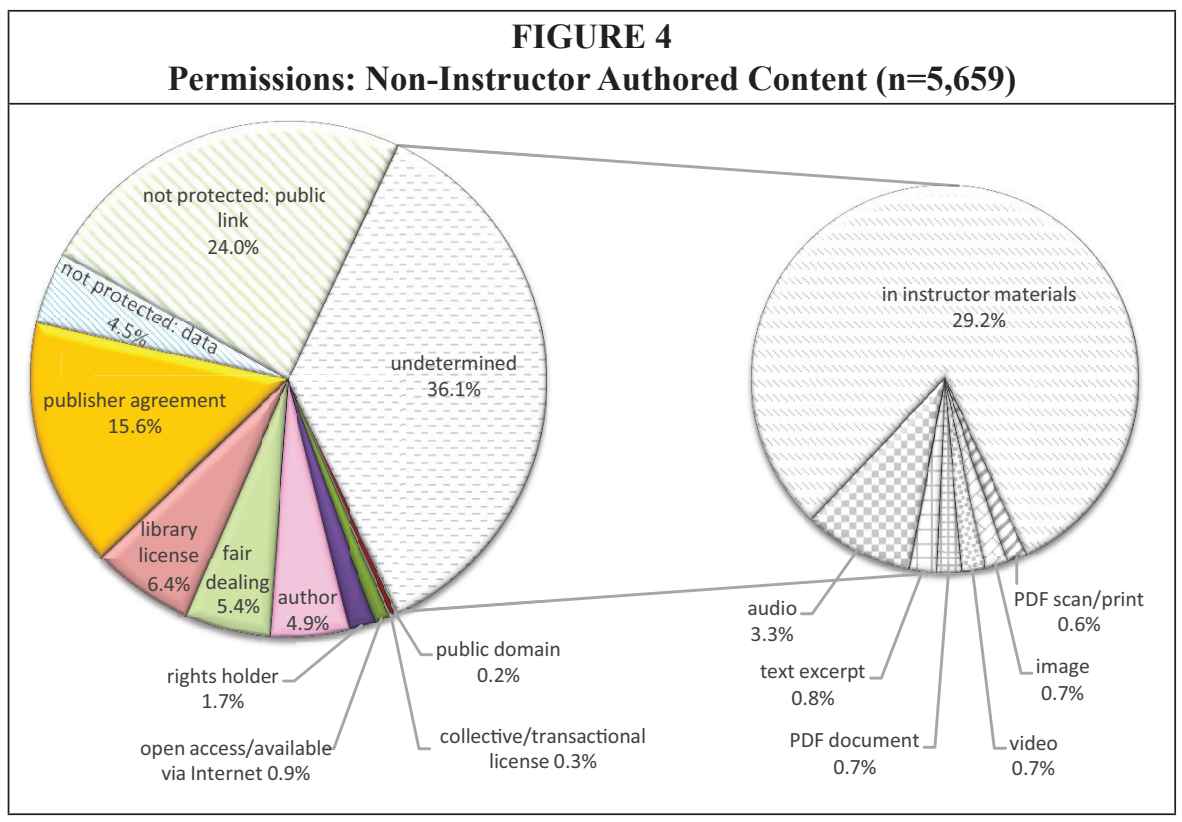

About 36 percent of non-instructor-authored materials lacked sufficient attribution, leaving their copyright status undeterminable. About three-quarters of materials having an undetermined status - approximately 29 percent of all noninstructor LMS materials - were items embedded "in course instructor materials," which most often were lesson slides. ${ }^{64}$ Further analysis of the embedded items showed that all were audiovisual materials of various types.

\section{LMS Copying}

As non-instructor-authored content having an undetermined copyright status included only a very small amount of textual materials (about $2 \%$ ), identification of a probable permission source was possible for almost all readings viewed in the LMS. Table 1 summarizes the results of permission analyses, for a total of 2,007 works viewed in spring 2012 LMS courses, of which more than 93 percent were course readings. The most frequently assigned probable permission source was publisher agreement, followed by library license and fair dealing, which together account for about 77 percent of the assessed materials. Collective license as a permission source applied to less than 1 percent of LMS materials.

\section{Coursepack Copying}

A coursepack in print or digital format was produced for 71 courses taught in the spring 2012 semester. While most of the coursepacks were in print format, 6 were distributed online via the LMS as part of a digital course readings pilot project. ${ }^{65}$ For 9 print 


\begin{tabular}{|l|c|c|}
\hline \multicolumn{3}{|c|}{ TABLE 1 } \\
\hline & Npring 2012 LMS Permission Sources \\
\hline Public domain (permission not required) & 14 & \% of Total \\
\hline Publisher agreement & 884 & $0.7 \%$ \\
\hline Library license & 361 & $44.0 \%$ \\
\hline Fair dealing & 306 & $18.0 \%$ \\
\hline Author & 275 & $15.2 \%$ \\
\hline Rights holder & 96 & $13.7 \%$ \\
\hline Open access/available via Internet & 53 & $4.8 \%$ \\
\hline Transactional license & 11 & $2.6 \%$ \\
\hline Collective license & 7 & $0.5 \%$ \\
\hline TOTAL & 2007 & $0.3 \%$ \\
\hline
\end{tabular}

coursepacks, permission analyses were not needed, as they contained only instructorauthored materials. A total of 799 readings were used in 57 coursepacks comprising materials authored predominantly by individuals other than course instructors. About 57 percent of coursepack readings were book chapters, 20 percent were journal or newspaper articles, 16 percent comprised literary extracts and business cases, and 6 percent comprised readings from other kinds of works.

The reassessed permission analyses for spring 2012 coursepack readings are summarized in table 2. During the actual spring 2012 semester, fair dealing was not relied on at all for any coursepack readings, but the reassessment that applied the university's current fair dealing guidelines yields the finding that permission for more than 68 percent of those readings is provided by the Copyright Act under fair dealing. The next most important permission source is library license, which, in combination with fair dealing, accounts for more than three-quarters of permissions sources for coursepack readings. Collective license accounts for 5 percent of the semester's coursepack permissions.

\section{Library Reserve Copying}

In spring 2012, instructors asked for 132 print readings to be placed on library reserve for 25 courses. About 43 percent were book chapters, 53 percent were journal and

\begin{tabular}{|l|c|c|}
\hline \multicolumn{3}{|c|}{ TABLE 2 } \\
\hline & Number of Readings & \% of Total \\
\hline Public domain (permission not required) & 23 & $2.9 \%$ \\
\hline Fair dealing & 545 & $68.2 \%$ \\
\hline Library license & 73 & $9.1 \%$ \\
\hline Open access/available via Internet & 47 & $5.9 \%$ \\
\hline Transactional license & 43 & $5.4 \%$ \\
\hline Collective license & 40 & $5.0 \%$ \\
\hline Author & 25 & $3.1 \%$ \\
\hline Publisher agreement & 3 & $0.4 \%$ \\
\hline TOTAL & 799 & $100 \%$ \\
\hline
\end{tabular}


newspaper articles, and 4 percent was composed of other types of readings. Table 3 summarizes the reassessed permission analyses for submitted reserve readings. While only 45 readings actually remained on reserve in spring 2012,66 the reassessment reveals that a permission source enabling distribution via print reserve is identifiable for all but 6 of the readings. The proportion of reserve readings for which fair dealing represents a permission source jumped from 34.1 percent in the spring 2012 assessment to 59.1 percent in the reassessment. The reassessed permission source for most of the remaining readings is a library license. Collective licenses and transactional licenses together represent permission sources accounting for less than 3 percent of spring 2012 reserve readings.

\section{Spring 2012 Course Copying}

To assemble an integrated picture of a semester's worth of course-related copying, the permission analyses for copied materials made available via the LMS, coursepacks, and library reserve were aggregated. Table 4 presents an overview of the permission sources for all spring 2012 course materials considered in this study. The most frequently relied-on permission source, fair dealing, was applicable to just under one-third of assessed materials, with publisher agreement following closely behind. The top three permission sources most frequently applicable to the semester's copied course materials are fair dealing, publisher agreement, and library license, together accounting for 78 percent of all assessed materials. Across all three modes of course copying considered in the study, collective license as a permission source accounts for less than 2 percent of assessed works.

\section{Discussion}

\section{Kinds of Works Copied}

The examination of works copied as spring 2012 course materials reveals that the range of copyright-protected materials distributed via the LMS was different from that seen in coursepacks and reserve readings. Book chapters and journal articles together account for almost all $(96 \%)$ of copies made available on reserve and more than three-quarters (77\%) of copies reproduced in coursepacks. If we consider the nature of literary extracts (such as poems or short stories) to be comparable to that of book chapters and the form of business cases to be roughly comparable to journal articles, ${ }^{67}$ then folding in literary works and business cases with chapters and articles raises the proportion of coursepack materials accounted for by chapter- and article-like content to 94 percent. In any case, the kinds of materials copied for coursepacks and library reserve, on the whole, are similarly strongly weighted toward published textual excerpts taken from books and journals.

\begin{tabular}{|l|c|c|}
\hline \multicolumn{3}{|c|}{ TABLE 3 } \\
Spring 2012 Library Reserve Permission Sources \\
\hline & Number of Readings & \% of Total \\
\hline Public domain (permission not required) & 1 & $0.8 \%$ \\
\hline Fair dealing & 78 & $59.1 \%$ \\
\hline Library license & 42 & $31.8 \%$ \\
\hline Open access/Available via Internet & 2 & $1.5 \%$ \\
\hline Collective license & 2 & $1.5 \%$ \\
\hline Transactional license & 1 & $0.8 \%$ \\
\hline Copied excerpt replaced by original book & 6 & $4.5 \%$ \\
\hline TOTAL & 132 & $100 \%$ \\
\hline
\end{tabular}




\begin{tabular}{|l|c|c|c|c|c|}
\hline \multicolumn{5}{|c|}{ TABLE 4 } \\
\hline \multicolumn{5}{|c|}{ Number of Readings } \\
\hline & LMS & Coursepack & $\begin{array}{c}\text { Library } \\
\text { Reserve }\end{array}$ & $\begin{array}{c}\text { Readings } \\
\text { Totals }\end{array}$ & $\begin{array}{c}\% \text { of } \\
\text { Totals }\end{array}$ \\
\hline $\begin{array}{l}\text { Public domain (permission not } \\
\text { required) }\end{array}$ & 14 & 23 & 1 & 38 & $1.3 \%$ \\
\hline Fair dealing & 306 & 545 & 78 & 929 & $31.6 \%$ \\
\hline Publisher agreement & 884 & 3 & & 887 & $30.2 \%$ \\
\hline Library license & 361 & 73 & 42 & 476 & $16.2 \%$ \\
\hline Author & 275 & 25 & & 300 & $10.2 \%$ \\
\hline Open access/available via Internet & 53 & 47 & 2 & 102 & $3.5 \%$ \\
\hline Rights holder & 96 & & & 96 & $3.3 \%$ \\
\hline Transactional license & 11 & 43 & 1 & 55 & $1.9 \%$ \\
\hline Collective license & 7 & 40 & 2 & 49 & $1.7 \%$ \\
\hline $\begin{array}{l}\text { Copied excerpt replaced by original } \\
\text { work }\end{array}$ & & & 6 & 6 & $0.2 \%$ \\
\hline Semester Totals & 2007 & 799 & 132 & 2938 & $100 \%$ \\
\hline
\end{tabular}

In contrast, the range of LMS materials is much broader and includes nontextual as well as textual content. At one end of the spectrum lie a few large works such as entire books and manuals. Clustered at the opposite end are audio and video excerpts and many small, chiefly visual works or excerpts such as graphics, photographs, charts, and graphs most often embedded in instructor-authored materials. Occupying the wide middle range are articles and chapters, along with reports, literary or musical works, and other written or notated materials. That textbook publisher-created teaching resources were the most heavily used materials in LMS courses is surprising: they account for a larger proportion (38\%) of LMS content than articles and chapters combined (33\%). If we add business cases and literary/musical works to articles and chapters, their combined percentage (39\%) is similar to that of publisher resources, but it still represents a small proportion of LMS materials when compared to the preponderance of articles and chapters in coursepacks and reserve readings.

\section{Sources of Permission}

Despite wide differences in the kinds of copied materials distributed via the LMS, coursepacks and library reserve, the most frequently applicable permission sources constitute a small pool of only three - fair dealing, library license, and publisher agreement-which combine to account for 77 percent to 91 percent of permissions needed within the three modes of distribution.

Fair dealing represents a permission source for 68.2 percent and 59.1 percent of coursepack and reserve readings, respectively; in the LMS, it accounts for 15.2 percent of probable permission sources. On the whole, fair dealing is the permission source relied on most frequently by the university. The frequent applicability of fair dealing to the copying investigated in this study may indicate a renewed ability of the Copyright Act to maintain "a balance between promoting the public interest in the encouragement and dissemination of works of the arts and intellect and obtaining a just reward for the creator." 68 That is, recent changes in Canadian copyright law perhaps enable the Act 
to further copyright's original goals, encouragement of learning and promotion of the progress of science and useful arts, ${ }^{69}$ in a manner producing more substantive balance than did the 1990s-initiated collective licensing regime.

For coursepack and reserve readings, library licenses are the second most important permission source, thus confirming the value of licensed digital content to the academic enterprise. Some have argued that significant amounts of needed permissions are covered under the terms of licenses negotiated directly with publishers of full-text content, ${ }^{70}$ but it is nevertheless useful to have factual evidence showing how much of an institution's instructional copying they cover. Library licenses account for 9.1 percent, 18 percent, and 31.8 percent of the copied materials distributed via coursepacks, the LMS, and library reserve, respectively. Across all modes of distribution, library licenses account for the third-largest percentage of permissions needed for spring 2012 copied course materials.

It is noteworthy that many library licenses negotiated by consortia are based on model license agreements permitting uses that are much broader and more flexibly attuned to the needs of postsecondary learning and teaching than the kinds of copying permissible under fair dealing. For example, the CRKN model licence, which forms the basis for many of the university's consortially negotiated licenses, contains a usage clause permitting authorized users to "Distribute single copies of individual articles or items of the Licensed Materials in print or electronic form to other Authorized Users; for the avoidance of doubt, this sub-clause shall include the distribution of a copy for teaching purposes to all individual student Authorized Users in a class at a Member."71

While permissions for 90.9 percent of library reserve copies and 77.3 percent of coursepack copies are provided by fair dealing and library licenses combined, at 32.2 percent the proportion of probable permission sources they represent for LMS copied materials is markedly smaller. We might suppose this is due to fewer readings distributed via the LMS, but fair dealing and library licenses together account for 667 LMS readings and 618 coursepack readings. The modest proportion of LMS permissions accounted for by fair dealing and library licenses is a residual effect of heavy use of materials dependent on publisher agreements representing 44 percent of probable permission sources for LMS materials. This means the largest proportion of needed LMS permissions was in the hands of a few textbook publishers. In fact, publisher agreement represents the second most frequently applicable permission source across all modes of distribution even though its relevance is limited almost exclusively to LMS course materials.

Open access licenses and the new statutory users' right, "Work available through Internet," are among the permission sources the university relied on least frequently, but even so, together they were applicable to spring 2012 course materials twice as often as transactional and collective licenses.

Transactional licenses were applicable almost exclusively to business cases, which have never been covered by Canadian collective blanket licenses. Spring 2012 permissions attributable to the university's blanket license represented the smallest proportion of all needed permissions, numbering fewer than 50. And in almost all cases, an alternative permission source-a transactional license from the Copyright Clearance Center-was determined to be available. Although the number of readings in the public domain was small, the public domain is noted here because it is "the law's primary safe-guard of the raw material that makes authorship possible"72 and an important corollary to copyright.

\section{Permissions Management Implications}

Enabled by the Supreme Court's "large and liberal interpretation" of research and other fair dealing purposes under the Copyright Act in $\mathrm{CCH}^{73}$ and its ruling in Alberta (Educa- 
tion) that teachers' copying of short excerpts for student use can qualify as fair dealing, the users' right of fair dealing was the most frequently applicable permission source in this study's permission analyses. Fair dealing is a statutory provision available to all users in Canada and is one of the most important permission sources for educational copying in general. It is potentially applicable to all copyrighted works, barring contractual agreements to the contrary. In addition, on the issue of whether an available license negates the applicability of fair dealing, the Supreme Court stated in $\mathrm{CCH}$ :

The availability of a licence is not relevant to deciding whether a dealing has been fair... If a copyright owner were allowed to license people to use its work and then point to a person's decision not to obtain a licence as proof that his or her dealings were not fair, this would extend the scope of the owner's monopoly over the use of his or her work in a manner that would not be consistent with the Copyright Act's balance between owner's rights and user's interests. ${ }^{74}$

At the same time, fair dealing is not a simple, all-purpose solution to an educational institution's permission needs. Since fair dealing is not defined in the Copyright Act, it requires interpretation and a certain amount of risk analysis. Instructors who are responsible for clearing permissions for materials used in LMS courses need to understand, among other things, the purpose of the Copyright Act and how to evaluate whether a particular dealing with a work is fair. The matter is further complicated by widely divergent views on the kinds of educational copying that may qualify as fair dealing. CMEC characterizes its revised fair dealing guidelines as a safe harbor of minimum levels of copying that teachers can perform, ${ }^{75}$ but CMEC's guidelines and those adopted by AUCC and ACCC are elsewhere declared to be "unacceptable to Canadian creators and publishers."76

The fair dealing dispute has been intensified by lawsuits. In 2013, Access Copyright launched a suit against an Ontario university, alleging its fair dealing guidelines "authorize and encourage copying that is not supported by the law"; $; 7$ and, in 2014, Copibec filed a class action suit against a Quebec university for copyright infringement. ${ }^{78}$ The equally contentious issue of the pending postsecondary tariff also looms ahead, a key question being whether, once certified, the tariff effectively becomes mandatory for institutions that make any unauthorized use of works covered by the tariff. It is the considered view of one legal scholar that the idea of a mandatory tariff has no basis in law, but the matter has yet to be decided in a court of law. ${ }^{79}$ While these legal processes unfold, a reasonable way forward is the exercise of fair dealing, when applicable, in compliance with guidelines reflecting the educational community consensus ${ }^{80}$ in combination with continuing efforts to help instructors understand the contours of copyright, statutory users' rights, and usage terms of library licenses.

Given the inherent risks in relying on fair dealing and other users' rights as permission sources, library licenses permitting a wide range of usages beyond fair dealing amounts represent a less risky, possibly underused permission source for educational copying. The current greater reliance on fair dealing to cover permissions for readings is perhaps partly due to scarce licensed digital versions of older print publications in some disciplinary areas. Another factor may be lack of a convenient means to search all available licensed content to find suitable readings for particular courses. The latter could perhaps be addressed by investigating the feasibility of creating a permissionscleared database of the university's licensed and open access articles and books. If successfully established, instructors could be encouraged to use the precleared database when developing new courses or new reading lists. 
Publisher agreements as a permission source for teaching resources tied to specific textbooks generally pose few permission management concerns since they are freely available to instructors who are responsible for complying with the terms and conditions of agreements. In this study, publisher-owned teaching resources used in the LMS most often corresponded with the adopted course textbook. Whether copying of teaching resources tied to specific editions of textbooks are permitted when the instructor has not adopted the corresponding textbook for the course is a matter on which different publishers may have variant policies. On the few occasions when such discrepancies were noticed in this study, they usually involved use of materials associated with an older edition of the adopted course textbook. A guide providing information on publishers' policies and permitted uses relating to teaching resources tied to particular textbooks is likely to be helpful to instructors who wish to use publishers' teaching resources in LMS courses. ${ }^{81}$

Although open access licenses and the new users' rights under the Copyright Act permitting copying of freely available Internet materials represent a small proportion of the overall permissions needed in this study, they are important because they provide publicly available permissions for educational uses and exclude cost as an access barrier, thereby advancing copyright's fundamental purpose of encouraging learning. In addition, ensuring public access to the outcomes of publicly funded research is becoming a common requirement under policies adopted by research-granting organizations. ${ }^{82}$ Continued development of the open access movement should result in progressively wider availability of freely accessible scholarly publications and perhaps a decrease in dependence on costly, less easily obtained permissions.

This study's analyses indicate that presently there is little reason to consider a blanket collective license as an important source of needed permissions. Across all course materials assessed in the study, collective licensing was the least frequently applicable permission source, accounting for less than 2 percent of copied materials. The royalty rate stipulated in the 2011-2015 AUCC model license (\$26.00 per FTE) far surpasses the permission costs reasonably attributable to the 49 spring 2012 copyrighted course readings falling within the university's blanket license repertoire that were not otherwise covered by a statutory users' right, library license, open access, or fee-free copyright owner permission.

\section{Limitations and Further Research}

One limitation of this study is its assumption that the "case" under investigation, spring 2012 course-related copying, is representative of copying that takes place throughout the school year. But some differences may possibly distinguish the fall and spring semesters in terms of the kinds of materials copied or permission sources needed. For instance, the fall semester typically encompasses a slightly higher number of courses, and courses at different levels of study may be distributed somewhat differently over the two semesters. A follow-up study could examine course-related copying of a recent fall semester to investigate whether differences are observed that call for a revised picture of the university's course-related copying and adjusted conclusions about needed permissions.

Because this study produced a snapshot of educational copying and permissions, an inherent limitation is the risk that it may quickly become dated if significant changes occur in the university's copying environment. Since spring 2012, the university library and CAO have introduced a new e-reserve service that has now virtually replaced the former print-based library reserve service, and the bookstore continues to explore new ways of providing coursepack production services in print and/or digital formats, depending on instructors' preferences. As well, instructor interest in using the 
LMS as a self-serve means of distributing courses may have increased since the spring 2012 semester when the current LMS had just recently been introduced. A follow-up study could update the spring 2012 snapshot by examining a more recent semester's educational copying.

In addition, permissions assessment of LMS materials was an interpretive exercise carried out by the researcher based on observed information on copied materials and instructors' notations, with no ability to seek clarification from instructors under the study's approved ethics protocol. Another inherent limitation is therefore the necessarily tentative nature of the permission sources thought to be applicable to copied LMS materials.

A further limitation is this study's restricted focus on three modes of course-related copying. There are other means of distributing copies of course materials to students including e-mail, social media platforms, and the use of online environments other than the institutional LMS. A future study could probe a broader range of copying modes that would perhaps call for a different approach such as survey and/or focus group research.

A final limitation noted here is the study's focus on copied materials to better understand the kinds of educational copying that occur within the university and the kinds of required permissions. Instructors' educational copying, however, is likely shaped, at least in part, by the kinds of copying they believe are permissible. Although copying that is permissible and impermissible in particular circumstances is a complex matter on which even legal scholars, lawyers, and judges often disagree, further research on instructors' understandings of copyright and course-related permissions clearance processes could add an interesting and informative dimension to an overall picture of the institution's course-related copying and management of its copyright permission needs.

\section{Conclusion}

In some respects, the copyright landscape in which Canadian educational institutions find themselves today contains more questions than ever before regarding the interdependent interests and rights of copyright owners and public users. Education is now recognized under the Copyright Act as a fair dealing purpose, and the Supreme Court decision in Alberta (Education) established unequivocally that educational copying can qualify as fair dealing if, on balance, a properly conducted analysis shows the dealing to be fair. But there remain considerable differences in how copyright owners and educators understand the scope of fair dealing for educational purposes, two prominent examples being the lawsuits launched by collectives against two universities that have opted out of blanket licensing.

Moreover, uncertainties abound regarding outcomes of the Copyright Board's tariff certification processes, which are ongoing with an unclear time frame for resolution.

As an antidote to some uncertainties, this study contributes to a lightly covered area of the professional literature by describing one approach to constructing a reasonably complete evidence-based picture of course-related copying and permission sources. It may be of interest to other institutions that engage in similar kinds of educational copying or wish to undertake a similar evidence-based inquiry. Among the insights gained in this study is an understanding of copyrighted works used in LMS courses obtained by examining materials in situ that is deeper than would have resulted from analyses conducted solely on course syllabi and reading lists. Another is recognition that adequate institutionwide permissions analyses will necessarily include LMS courses, since more than two-thirds of course-related copying occurred in the LMS. A third insight is an evidence-based ranking of permission sources most frequently relied on by the university, which shows the relevance of statutory users' rights and library licenses 
to far exceed that of blanket licensing. Thus, if the university contemplates becoming an opt-out institution once again, it will have a much enriched understanding of the copyright status and applicable permission sources for the whole of its course-related copying.

\section{Notes}

1. Two copyright collective societies administer owners' rights in literary works in Canada: COPIBEC operates in the province of Quebec and Access Copyright operates in the rest of Canada.

2. Patricia Aufderheide and Peter Jaszi, Reclaiming Fair Use: How to Put Balance Back into Copyright (Chicago, Ill.: University of Chicago Press, 2011), 18-19; Joan T. Dalton, "Electronic Reserves and the Copyright Challenge in Canada," Journal of Interlibrary Loan, Document Delivery E Electronic Reserve 17, no. 1/2 (2007): 113; Janice T. Pilch, "Fair Use and Beyond: The Status of Copyright Limitations and Exceptions in the Commonwealth of Independent States," College $\mathcal{E}$ Research Libraries 65, no. 6 (2004): 468-70.

3. Samuel E. Trosow, "The Changing Landscape of Academic Libraries and Copyright Policy," in In the Public Interest: The Future of Canadian Copyright Law, ed. M. Geist (Toronto: Irwin Law, 2005), 397-400; Margaret Ann Wilkinson, "Filtering the Flow from the Fountains of Knowledge: Access and Copyright in Education and Libraries," in In the Public Interest: The Future of Canadian Copyright Law, ed. M. Geist (Toronto: Irwin Law, 2005), 344-49; American Library Association, "Fair Use and Electronic Reserves," available online at www.ala.org/advocacy/copyright/fairuse/ fairuseandelectronicreserves [accessed 5 September 2014].

4. Tobi Fineberg, "Copyright and Course Management Systems: Educational Use of Copyrighted Materials in the United States and the United Kingdom," Libri: International Journal of Libraries \& Information Services 59, no. 4 (2009): 238-47; Prudence Adler, Brandon Butler, Patricia Aufderheide, and Peter Jaszi, "Fair Use Challenges in Academic and Research Libraries" (Washington, D.C.: Association of Research Libraries, 2010), available online at http://digitalcommons. wcl.american.edu/cgi/viewcontent.cgi?article=1002\&context=pijip_copyright [accessed 20 May 2013]; Janis H. Bruwelheide, "Myths and Misconceptions from Perspectives of Educators and Copyright Owners," in Growing Pains: Adapting Copyright for Libraries, Education, and Society, ed. L.N. Gasaway (Littleton, CO: F.B. Rothman, 1997), 287-314; Canadian Copyright Institute, A Fair and Better Way Forward, (Toronto, Ontario: Canadian Copyright Institute, 2013), 8, available online at www.thecci.ca/docs/A-FAIR-AND-BETTER-WAY-FORWARD.pdf [accessed 19 March 2014].

5. Nancy L. Eaton, "Pennsylvania State University: Our Evaluation of the Copyright Clearance Center Blanket License," in [Should You or Shouldn't You]: The Copyright Clearance Center Blanket License: Is It Right For Your Library? (Ipswich, Mass.: EBSCO Information Services, 2008), 3-5, available online at http://www2.ebsco.com/en-us/NewsCenter/publications/vantagepoint/ Documents/20321-Vantage-Point-web.pdf [accessed 14 March 2015]; Paul Davidson, “Opting Out: Why Some Universities Are Opting Out of Access Copyright," October 17, 2011, available online at www.aucc.ca/media-room/news-and-commentary/opting-out-why-some-universitiesare-opting-out-of-access-copyright/ [accessed 26 August 2014].

6. Prudence W. Dalrymple, "Evidence-Based Practice," in Encyclopedia of Library and Information Sciences, eds. M.J. Bates and M.N. Maack (Boca Raton, Fla.: CRC Press, 2010), 3: 1790-96.

7. Janet Collins, "Ontario School Boards Sign with Cancopy," Feliciter 37, no. 9 (1991): 1, 16; Maureen Webb, "CanCopy Negotiates Model Licence Agreement with AUCC," CAUT Bulletin 41, no. 7 (1994): 6 .

8. Prior to the Canadian Copyright Act amendments enacted in 2012, fair dealing did not explicitly cover education as the fair dealing purposes enumerated in s. 29, 29.1 and 29.2 of the Act comprised research, private study, criticism, review and news reporting.

9. "Agreement Eases Copyright Woes," University Affairs 35, no. 5 (1994): 17.

10. Evidence presented by Pierre Killeen on behalf of ACCC to the House of Commons Standing Committee on Canadian Heritage, October 30, 1996. See www.parl.gc.ca/Content/HOC/Archives/ Committee/352/heri/evidence/32_96-10-30/heri-32-cover-e.html.

11. Webb, "CanCopy Negotiates Model Licence Agreement with AUCC," 6.

12. The preamble to the AUCC-Access Copyright blanket licenses in effect up to 2010 contained the following statements: "Whereas the Institution desires to continue to secure the right to reproduce copyright works for the purposes of education, research and higher learning which reproductions would be outside the scope of fair dealing under the Copyright Act R.S.C. 1985 c.C-42, as amended; and Whereas the parties do not agree on the scope of the said fair dealing." Documents on file with the author.

13. The clause states: “By entering into this Agreement neither party is agreeing or represent- 
ing in any way, either directly or indirectly, that the making of a single copy of all or a portion of a periodical article of a scientific, technical or scholarly nature and a single copy of a portion of any other Published Work, without the permission of the owner of copyright therein, is or is not an infringement of copyright." Documents on file with the author.

14. Webb, "CanCopy Negotiates Model Licence Agreement with AUCC," 6.

15. Prior to the first postsecondary license agreements negotiated by CANCOPY, the province of Quebec had signed an agreement on reprographic rights with the Union des écrivains du Quebec on behalf of Quebec schools, CEGEPs and universities. See "Agreement Eases Copyright Woes," 17.

16. Copyright Act, R.S.C., ch. C-42, s. 70.12 (1985) (Can.).

17. Howard P. Knopf, "CMEC Seeks Review of K-12 Copyright Board Tariff," Excess Copyright (blog), July 27, 2009, available online at http://excesscopyright.blogspot.ca/2009/07/cmec-seeksreview-of-k-12-copyright.html [accessed 14 March 2015].

18. Alberta (Education) v. Access Copyright, 2010 FCA 198, [2011] 3 F.C.R. 223.

19. Copyright Board of Canada, "Notice of the Board [Regarding the Status of Objectors to the 2011-2013 Postsecondary Tariff]," last modified November 15, 2010, available online at http:// www.cb-cda.gc.ca/avis-notice/index-e.html\#access2-15112010 [accessed 14 March 2015].

20. In fact, two Access Copyright postsecondary tariffs await Copyright Board certification: the proposal filed in 2010 covering 2011-2013, and a subsequent proposal filed in May 2013 covering 2014-2017. See www.cb-cda.gc.ca/tariffs-tarifs/proposed-proposes/reprographic-reprographie-e. html.

21. Copyright Board of Canada, Statement of Proposed Royalties to Be Collected by Access Copyright for the Reprographic Reproduction, in Canada, of Works in Its Repertoire: Post-Secondary Educational Institutions (2011-2013), available online at www.cb-cda.gc.ca/tariffs-tarifs/ proposed-proposes/2010/2009-06-11-1.pdf [accessed 14 September 2015]; Samuel Trosow, Scott Armstrong, and Brent Harasym, "Objections to the Proposed Access Copyright Post-Secondary Tariff and Its Progeny: A Working Paper," last modified August 14, 2012, available online at http:// ir.lib.uwo.ca/cgi/viewcontent.cgi? article=1026\&context=fimspub [accessed 1 November 2014].

22. Copyright Board of Canada, Interim Statement of Royalties to Be Collected by the Canadian Copyright Licensing Agency (Access Copyright) (as Amended on April 7, 2011) available online at www.cb-cda.gc.ca/tariffs-tarifs/proposed-proposes/2011/Revised_interim_tariff.pdf [accessed 14 September 2014].

23. Michael Geist, "The Access Copyright Interim Tariff Opt-out List," Michael Geist (blog), July 29, 2011, available online at www.michaelgeist.ca/2011/07/access-copyright-opt-out-list/ [accessed 12 March 2015].

24. Dara Lithwick and Maxime-Olivier Thibodeau, "Legislative Summary, Bill C-11: An Act to Amend the Copyright Act" (Ottawa, Ontario: Library of Parliament, 2011), available online at www.parl.gc.ca/Content/LOP/LegislativeSummaries/41/1/c11-e.pdf [accessed 16 March 2015].

25. The Copyright Pentalogy: How the Supreme Court of Canada Shook the Foundations of Canadian Copyright Law, ed. Michael A. Geist (Ottawa, Ontario: University of Ottawa Press, 2013).

26. Access Copyright, "U of T and Western Sign Agreement with Access Copyright," news release, January 30, 2012, available online at www.accesscopyright.ca/media/21943/u_of_t_and_ western_sign_agreement_with_access_copy right.pdf [accessed 24 November 2013].

27. Canadian Association of University Teachers, "Copyright Agreement with Western and Toronto a Bad and Unwarranted Deal," news release, February 2, 2012, available online at www. caut.ca/news/2012/02/02/copyright-agreement-with-western-and-toronto-a-bad-and-unwarranted-deal [accessed 22 November 2013].

28. Access Copyright, "Access Copyright Signs Model Licence with the Association of Universities and Colleges of Canada " news release, April 16, 2012, available online at http:// accesscopyright.ca/media/22883/access_copyright_aucc_model_agreement_media_release.pdf [accessed 24 November 2013]; "AUCC Model Licence," last modified April 2012, available online at http://arielkatz.org/wp-content/uploads/2012/04/2012-04-15-Model-licence-agreement_AC.pdf [accessed 19 March 2015].

29. Access Copyright, "Access Copyright Announces Agreement with the Association of Community Colleges of Canada on a Model License," news release, May 29, 2012, available online at www.accesscopyright.ca/media/23761/access_copyright_announces_agreement_with_the_asso ciation_of_community_colleges_of_canada_on_a_model_licence.pdf [accessed 24 November 2013].

30. An Act to Amend the Copyright Act, 2012 S.C., ch. 20 (Can.).

31. Most of the 2012 amendments to the Act, including the expansion of the fair dealing purposes, came into force on November 7, 2012.

32. Alberta (Education) v. Canadian Copyright Licensing Agency (Access Copyright), [2012] 2 S.C.R. 345; CCH Canadian Ltd. v. Law Society of Upper Canada, [2004] 1 S.C.R 339. 
33. SOCAN (Society of Composers, Authors and Music Publishers of Canada) v. Bell Canada, [2012] 2 S.C.R. 326.

34. Michael Geist, "Why Canadians Should Participate in the Sopa/Pipa Protest," Michael Geist (blog), January 17, 2012, available online at www.michaelgeist.ca/2012/01/canada-and-sopaprotest/ [accessed 15 March 2015].

35. University of Lethbridge, Fact Book 2013/2014 (Lethbridge, Alberta: University of Lethbridge, 2014), 152, available online at www.uleth.ca/dspace/handle/10133/3441 [accessed 13 October 2014]; University of Lethbridge, Calendar, 2014/2015, (Lethbridge, Alberta: The University, 2014), 12, available online at www.uleth.ca/ross/academic-calendar/2014-15 [accessed 16 September 2014].

36. Christopher B. Loring, "Library Reserves and Copyright: Thirty Years on and Still Changing," Library Acquisitions: Practice \& Theory 21, no. 1 (1997): 29-39.

37. Brice Austin, "A Brief History of Electronic Reserves," Journal of Interlibrary Loan, Document Delivery \& Information Supply 12, no. 2 (2001): 4.

38. Dalton, "Electronic Reserves and the Copyright Challenge in Canada," 98.

39. For example, an ARL statement on e-reserves and fair use cautions that its applicability is only to e-reserves and that fair use within LMS environments is "out of scope of this statement."; Association of Research Libraries, "Electronic Reserves and Fair Use," ARL Bimonthly Report no. 232 (2004): 7.

40. Laura Gasaway, "Course Management Software and Copyright," Information Outlook 7, no. 1 (2003): 7-9; Rosemary Talab, “Using Digital Materials in Online Courses: A Cautionary Tale of Georgia State University," TechTrends: Linking Research and Practice to Improve Learning 52, no. 4 (2008): 30-32.

41. Steven J. Bell and Michael J. Krasulski, “Electronic Reserves, Library Databases and Courseware: A Complementary Relationship," Journal of Interlibrary Loan, Document Delivery \& Electronic Reserves 15, no. 1 (2004): 75-85; Ophelia Cheung and Susan Patrick, "E-Reserve in Blackboard," Journal of Interlibrary Loan, Document Delivery E Electronic Reserve 17, no. 3 (2007): 129-43; Jodi Poe and Sonja McAbee, "Electronic Reserves, Copyright, and CMS Integration-Six Years Later," Journal of Access Services 5, no. 1/2 (2008): 251-63.

42. Astrid Oliver, "Current Practices and Philosophy on Electronic Reserves, Course Management Systems, and Copyright Compliance: A Survey of the Council of Public Liberal Arts Colleges Libraries," Journal of Interlibrary Loan, Document Delivery \& Electronic Reserves 18, no. 4 (2008): 425-37.

43. Kymberly Anne Goodson and Linda Frederiksen, "E-Reserves in Transition: Exploring New Possibilities in E-Reserves Service Delivery," Journal of Interlibrary Loan, Document Delivery E Electronic Reserve 21, no. 1/2 (2011): 33-56.

44. Dalrymple, "Evidence-Based Practice," 1791.

45. Michael Geist, "Fair Dealing Consensus Emerges within Canadian Educational Community," Michael Geist (blog), November 14, 2012, available online at www.michaelgeist.ca/content/ view/6698/125/ [accessed 20 December 2013].

46. Wanda Noel and Jordan Snel, Copyright Matters! Some Key Questions \& Answers, 3rd ed. (Toronto, Ontario: Council of Ministers of Education, 2012), available online at http://cmec.ca/ Publications/Lists/Publications/Attachments/291/Copyright_Matters.pdf [accessed 18 August 2014]; Michael Geist, “Educational Fair Dealing Policy Shows Why the Access Copyright Licence Provides Little Value," Michael Geist (blog), October 1, 2012, available online at www.michaelgeist.ca/?s="educational+fair+dealing+policy [accessed 6 October 2014]; Canadian Association of University Teachers, CAUT Guidelines for the Use of Copyrighted Material (Ottawa, Ontario: CAUT, 2013), May 25, 2014, available online at www.caut.ca/docs/default-source/copyright/revised-cautguidelines-for-the-use-of-copyrighted-material-\%28feb-2013\%29.pdf [accessed 28 September 2014]; Association of Universities and Colleges of Canada, "Fair Dealing Policy for Universities" (2014), available online at www.aucc.ca/fair-dealing-policy-for-universities/ [accessed 25 May 2014].

47. University of Lethbridge, "Guidelines for Copying under Fair Dealing," last modified January 2013, available online at www.uleth.ca/lib/copyright/documents/UofL\%20copying\%20 guidelines\%20poster-8x14-final.pdf [accessed 17 January 2013].

48. Copyright Act, s. 5.

49. CCH, 1 S.C.R. at $15-16$

50. Copyright Act, s. 6.

51. Copyright Act, s. 3.

52. David Vaver, Intellectual Property Law: Copyright, Patents, Trade-Marks, 2nd ed. (Toronto, Ontario: Irwin Law, 2011), 182.

53. Warman v. Fournier, 2012 FC 803 (CanLII).

54. Crookes v. Newton, [2011] 3 S.C.R. 269 at 42.

55. Copyright Act, ss. 29-29.1. 
56. $\mathrm{CCH}, 1$ S.C.R. at $54-60$.

57. The library's Copyright Permissions Lookup tool provides access to information on permitted uses of subscribed e-journal articles. See www.uleth.ca/lib/copyright/index. asp?t1=permissions\& $2=$ journals.

58. Directory of Open Access Journals, "Definitions," available online at http://doaj.org/ about\#definitions [accessed 10 October 2014]; Creative Commons, "About the Licenses," available online at http://creativecommons.org/licenses/ [accessed 10 October 2014].

59. The Copyright Clearance Center is a US-based copyright licensing agency. See www. copyright.com.

60. Copyright Act, s. 30.04.

61. University of Lethbridge, Fact Book 2011/2012 (Lethbridge, Alberta: University of Lethbridge, 2013), 66-67, available online at https://www.uleth.ca/dspace/handle/10133/3397 [accessed 23 September 2014].

62. Of the 484 courses accessed by the researcher, 136 courses contained no course materials; or LMS objects were present but not viewable (for instance, quizzes, assignment submission boxes). It is also likely that some instructors for these courses used only administrative functions such as grade submission.

63. In figure 2, "course textbook publisher material" differs from "textbook publisher material" in that the latter represents material corresponding to textbooks that were not the course textbooks listed in course syllabi. This was often a matter of differing editions of a given textbook.

64. Because non-instructor-authored materials embedded in instructors' lesson slides were too numerous to tally individually, the unit of analysis was at the file, document, or webpage level. For example, if an instructor's lesson slide file contained 5 cartoons, 5 photos and 10 graphs, data coding reflected only one tally each under cartoon, photo, and graph.

65. Readings in 5 digital coursepacks that were also viewed in the LMS data collection phase were omitted from coursepack permission analyses to avoid double-counting.

66. The rest of the photocopied readings were replaced by links to online versions of the same content or replaced by books or journals owned by the library or the instructor.

67. For example, some peer-reviewed journals such as Journal of Business Case Studies, Journal of Business Cases and Applications and International Journal of Case Studies in Management focus almost exclusively on business cases.

68. Théberge v. Galerie d'Art du Petit Champlain Inc., 2002 SCC 34, [2002] 2 S.C.R. 336 at 30.

69. Statute of Anne, 1710 (UK) ch. c 19; U.S. Constitution art. I, sec. 8, cl. 8.

70. Stephen J. Toope, "[Letter to the Writer's Union of Canada]," last modified September 13, 2013, available online at http://copyright.ubc.ca/president-responds-to-the-writers-union-ofcanada/ [accessed 30 September 2013]; Michael Geist, "Toronto and UWO Confirm the Obvious: Access Copyright Licence Provides Little Value for Education," Michael Geist (blog), December 11, 2013, available online at http://www.michaelgeist.ca/2013/12/toronto-and-uwo-on-ac/ [accessed 19 March 2015].

71. Canadian Research Knowledge Network, "CRKN Model Licence," last modified April 7, 2014, available online at http://crkn.ca/sites/crkn.ca/files/site/crkn-model_license_final_2014-04-07. pdf [accessed 19 March 2015].

72. Jessica Litman, “The Public Domain," Emory Law Journal 39, no. 4 (1990): 967.

73. CCH, 1 S.C.R. at 51.

74. CCH, 1 S.C.R. at 70.

75. Council of Ministers of Ministers of Education, Canada, "Dealing Fairly with CopyrightProtected Works of Others: What Teachers Can and Cannot Do," last modified September 2013, available online at www.cmec.ca/docs/copyright/TEACHERS_PRESENTATION_SLIDES_EN.pdf [accessed 20 March 2015].

76. Canadian Copyright Institute, "A Fair and Better Way Forward," 8.

77. Access Copyright, "Canada's Writers and Publishers Take a Stand against Damaging Interpretations of Fair Dealing by the Education Sector," news release, April 8, 2013, available online at http://accesscopyright.ca/media/35670/2013-04-08_ac_statement.pdf [accessed 31 December 2013].

78. Copibec, “\$4 Million Class Action Lawsuit against Université Laval for Copyright Infringement," news release, November 10, 2014, available online at www.copibec.qc.ca/Portals/0/ Fichiers_PDF_anglais/NEWS\%20RELEASE-Copibec\%20Novembre\%2010\%202014.pdf [accessed 14 January 2015].

79. Ariel Katz, "Spectre: Canadian Copyright and the Mandatory Tariff," Social Science Research Network abstract 2544721, last modified January 7, 2015, available online at http://ssrn. com/abstract=2544721 [accessed 14 January 2015].

80. Geist, "Fair Dealing Consensus Emerges."

81. For example, see the guide created by Meaghan Shannon, "Using Textbooks and Instruc- 
tional Materials in the Classroom," last modified March 16, 2015, available online at https:// fanshawec.libguides.com/content.php?pid=209668\&sid=2906794 [accessed 19 March 2015].

82. Karla L. Hahn, "Two New Policies Widen the Path to Balanced Copyright Management," College \& Research Libraries News 69, no. 7 (2008): 398-400; Government of Canada, "Tri-Agency Open Access Policy on Publications," last modified 27 February 2015, available online at www. science.gc.ca/default.asp?lang=En\&n=F6765465-1 [accessed 28 February 2015]. 